\title{
Predation by Atlantic cod Gadus morhua on northern shrimp Pandalus borealis in inshore and offshore areas of Iceland
}

\author{
Ingibjörg G. Jónsdóttir*, Höskuldur Björnsson, Unnur Skúladóttir
}

Marine Research Institute, Skúlagata 4, PO Box 1390, 121 Reykjavík, Iceland

\begin{abstract}
Northern shrimp Pandalus borealis is found in both inshore and offshore areas around Iceland, where it has supported an important commercial fishery. However, in the past $15 \mathrm{yr}$ the northern shrimp population has decreased in size and collapsed in most of the inshore areas. In this study, the importance of Atlantic cod Gadus morhua on northern shrimp stock dynamics was studied by comparing stomach contents of cod between 2 different habitats, inshore and offshore northern shrimp fishery areas. Many prey items were observed in cod stomachs, but only a few dominated. The most important prey types, in decreasing order of importance, included northern shrimp, fish and euphausiids in the inshore area, as opposed to capelin Mallotus villosus, other fish species, northern ambereye Hymenodora glacialis and northern shrimp in the offshore area. Low northern shrimp biomass was observed during periods of high cod density, suggesting that predation by cod affected northern shrimp biomass in both areas.
\end{abstract}

KEY WORDS: Northern shrimp $\cdot$ Cod $\cdot$ Predation $\cdot$ Species interaction $\cdot$ Temperature

\section{INTRODUCTION}

Northern shrimp Pandalus borealis is targeted by commercial fisheries and is also of great importance as prey in the marine food web. Various fish species, mammals, sea birds and invertebrates, feed on shrimp (Parsons 2005). Demersal fishes, especially Atlantic cod Gadus morhua, are important predators on northern shrimp throughout Atlantic waters (Stefánsson et al. 1998, Berenboim et al. 2000, Sousa et al. 2006, Fraser et al. 2008, Campbell et al. 2011). Close linkage has been described between northern shrimp and cod, and predation can have strong effects on the development of shrimp stocks (Worm \& Myers 2003). The biological interactions between gadoids and northern shrimp are, however, poorly understood. Valuable information into the stock dynamics may be gained by comparing predation between areas.

Predation by cod on demersal stages of northern shrimp has been well documented in various geo- graphical areas (Albers \& Anderson 1985, Magnússon \& Pálsson 1989, Lilly et al. 2000). These studies have demonstrated the importance of northern shrimp in the diet of cod, but have also noted that the contribution by northern shrimp to the cod diet can vary greatly with area (Rose \& O'Driscoll 2002), time of year (Pálsson \& Björnsson 2011) and size of cod (Albers \& Anderson 1985, Berenboim et al. 2000). The consumption of northern shrimp by cod can also be quite variable over years (Mehl 1989, Pálsson \& Björnsson 2011), and sometimes it may represent a greater source of mortality than commercial fishing pressure (Savenkoff et al. 2007).

Northern shrimp are considered to represent localized populations in inshore and offshore Icelandic areas, with genetic differences and limited connectivity during adult stages (Jónsdóttir et al. 1998). In the 1980s and 1990s northern shrimp was one of the most important commercial species in Icelandic waters. However, in the past $15 \mathrm{yr}$ the northern 
shrimp populations have declined and most of the inshore populations have collapsed (Anonymous 2010). Northern shrimp fishing is regulated by areaspecific total allowable catches, which are determined based on results from annual surveys. Due to a poor state of the stocks, all but 2 inshore areas around Iceland are now closed for northern shrimp fishing. The northern shrimp resource in the offshore area north/northeast of Iceland was not as severely impacted as were the inshore resources, but it did experience major depletion after 1996, following a rapid increase in cod biomass in the northern shrimp grounds.

In this study we compare the diet of cod between inshore and offshore areas of Iceland. To evaluate the potential effect of predation by cod on northern shrimp populations in different habitats, stomach contents of cod were compared between an inshore area (Ísafjardardjúp, northwest of Iceland) and the offshore shrimp fishing area north/northeast of Iceland. Data were available from northern shrimp surveys from 1999 to 2010, allowing both annual and spatial comparisons.

\section{MATERIALS AND METHODS}

The data used in the present study were collected during annual shrimp surveys of both inshore and offshore areas. The purpose of the surveys was to provide an index of the overall northern shrimp Pandalus borealis stock biomass to inform fishery management. The standardized surveys have been conducted every year since 1988, whereas cod Gadus morhua stomach examination has only been conducted since 1998 and 1999 in the offshore and inshore areas, respectively, and so only data since 1999 were used in this study.

The inshore area chosen for this study, Ísafjardardjúp, is the largest fjord on the Westfjord peninsula in the northwest of Iceland (Fig. 1). The fjord is $75 \mathrm{~km}$ long, and the width at the mouth is approximately $20 \mathrm{~km}$. The depth in the middle of the fjord is 110 to $130 \mathrm{~m}$, but closer to the coast it is about 40 to $60 \mathrm{~m}$. Ísafjardardjúp does not have a sill near the mouth, and the water exchange into the fjord is fairly unrestricted. During September and October, the survey utilizes a standard shrimp bottom trawl of 1000 meshes in standard tows of 2 nautical miles, during daylight hours only, at a tow speed of 2.0 to 2.2 knots. The codend has an open mesh size of $37 \mathrm{~mm}(42 \mathrm{~mm}$ whole mesh size). The distance between the wing ends is $14.7 \mathrm{~m}$, and the mean $( \pm \mathrm{SD})$ vertical opening is $4.6 \pm 0.3 \mathrm{~m}$. In order to sample fish of all size classes, a sorting grid is not used. The survey includes 54 fixed stations annually at 39 to $155 \mathrm{~m}$ depth (Fig. 1). In 2006, 2009 and 2010, the sampling was reduced to 28 to 31 stations.

The offshore survey takes place in July to August (starting in June in 2004) north, northeast and east of Iceland at depths ranging from 200 to $700 \mathrm{~m}$ (Fig. 1). The survey trawl is a standard shrimp bottom trawl of 1400 meshes, towed during daylight hours only, at a speed of 2.1 to 2.3 knots. The codend has a diamond mesh, with a mesh size of $37 \mathrm{~mm}$ open mesh (whole mesh size is $40 \mathrm{~mm}$ ). The distance between the wing ends is $17 \mathrm{~m}$, and the mean $( \pm \mathrm{SD})$ vertical opening is $6.0 \pm 0.4 \mathrm{~m}$. Approximately 190 stations were sampled each year from 1999 to 2005, but only 92 fixed stations have been sampled annually in more recent years (Fig. 1). Despite reduced coverage the overall survey area has remained unchanged. Tow length was reduced from 1.5 to 2.5 nautical miles from 1999

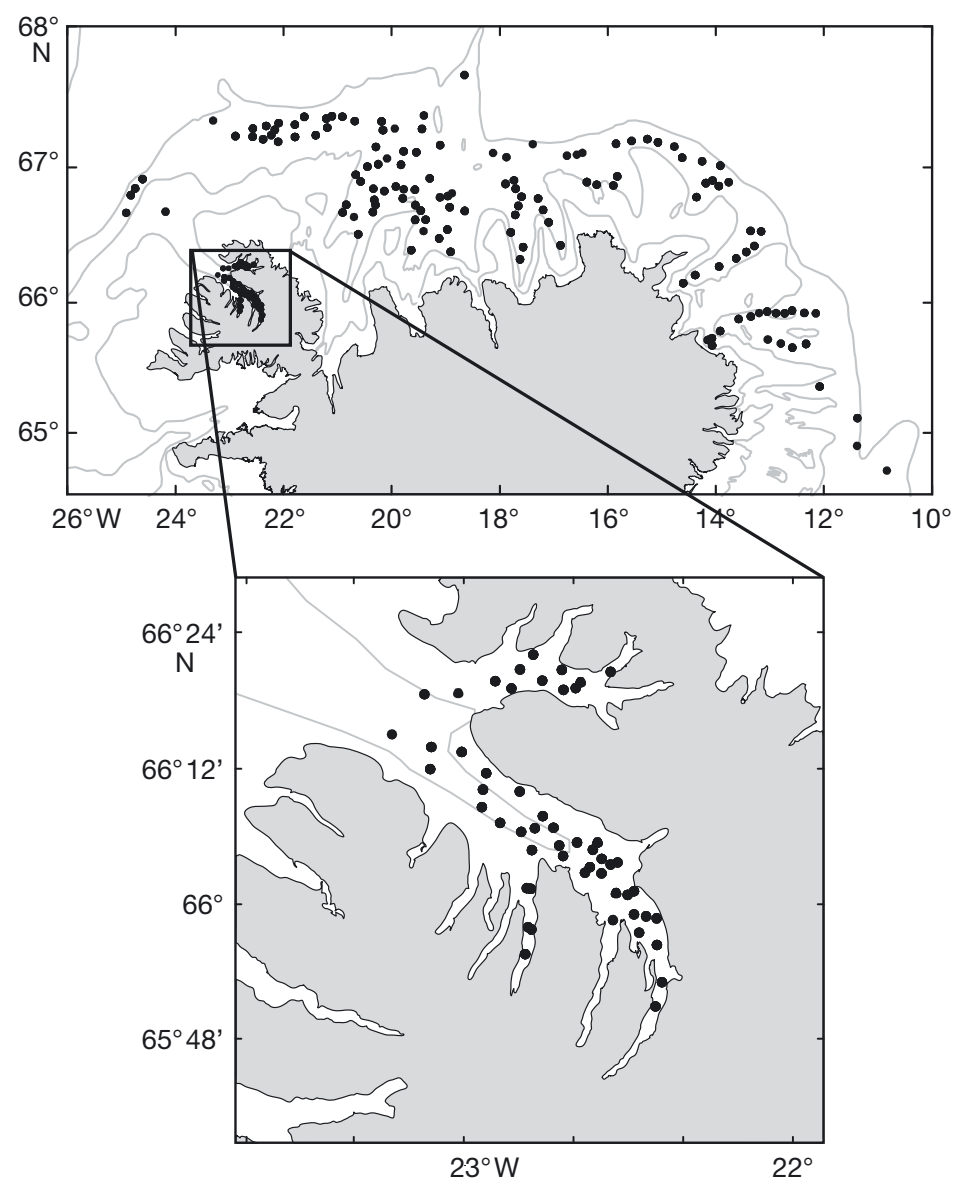

Fig. 1. Sampling locations in the annual shrimp surveys. Depth contours at 100, 200 and $500 \mathrm{~m}$. The inshore area is within the box and enlarged. Depth contours in inshore area at $100 \mathrm{~m}$ 
to 2003 to between 1.5 and 2.0 nautical miles in subsequent years. In order to sample fish of all size classes a sorting grid is not used.

Sea bottom temperature is determined at each station using a pre-calibrated trawl sensor (Scanmar) attached to the trawl headline. Sea bottom temperature was not determined in 2006 in the inshore area due to failure in the equipment. Each study area was divided into several sub-areas based on northern shrimp distribution. The northern shrimp stock biomass index was calculated using the sum of the mean biomass estimates per square kilometre, which was calculated for each sub-area using the swept-area method described by Sparre \& Venema (1989).

When available up to 5 Atlantic cod $(>15 \mathrm{~cm})$ were randomly sampled at each station for detailed analysis onboard. Total length (TL) of each cod was measured to the nearest centimetre, whole and gutted weight recorded, and otoliths removed for age determination. The stomachs were cut open, and the contents were macroscopically identified with all prey items classified to the lowest taxonomic level possible. To avoid possible bias from fish swallowing food items in the trawl, any prey items not displaying signs of digestive action were discounted. The number of individuals of each prey type was counted, and their wet weights were measured to the nearest whole gram. Data were reduced to 7 prey categories or groups, including the most prominent prey species, northern shrimp Pandalus borealis, northern ambereye Hymenodora glacialis and capelin Mallotus villosus. Other prey types were pooled into 4 main groups: (1) fish, (2) other shrimps, (3) euphausiids, and (4) all other prey types including other crustaceans, echinoderms, annelids, molluscs and unidentified items. The weight of each prey group was expressed as a percentage of the total weight of the stomach content. Furthermore, the mean total stomach fullness (TF) was calculated as:

$$
\mathrm{TF}=\frac{1}{N} \sum\left(\frac{W_{\mathrm{f}}}{\left(\mathrm{TL}_{\mathrm{f}}\right)^{3}} \times 10^{4}\right)
$$

and the mean shrimp stomach fullness (SF) as:

$$
\mathrm{SF}=\frac{1}{N} \sum\left(\frac{W_{\text {if }}}{\left(\mathrm{TL}_{\mathrm{f}}\right)^{3}} \times 10^{4}\right)
$$

where $N$ is the total number of fish, $W_{\mathrm{f}}$ is the total stomach content weight from each fish, $W_{\text {if }}$ is the weight of northern shrimp from each fish and $\mathrm{TL}_{\mathrm{f}}$ is the total length of cod in centimetres (Nielsen \& Andersen 2001). The stomach fullness data were not normally distributed, and the values were not normally distributed after naturallog transformation of the data. Therefore, a nonparametric test, the Kruskal-Wallis test, was used to test for differences in mean stomach fullness (TF and $\mathrm{SF}$ ) among years for both inshore and offshore areas.

\section{RESULTS}

\section{Biomass trends}

The northern shrimp Pandalus borealis biomass index in the inshore area decreased continuously from 1990 to 2004, while it increased in the offshore area until 1996, after which it declined (Fig. 2). High indices in 1990 and 1996 in the inshore and offshore areas, respectively, could be due to year-effects. In both areas, the indices declined sharply after 2001 and reached historically low levels in 2004. The populations recovered slightly in the following years, and, while the offshore population has been relatively stable in the past $5 \mathrm{yr}$, the inshore northern shrimp biomass index was again very low in 2009 and 2010 (Fig. 2).

The density index, based on catch rate of cod Gadus morhua (number of cod caught per trawling hour) was calculated separately for small $(\leq 15 \mathrm{~cm})$ and large cod $(>15 \mathrm{~cm})$. The density of small cod was much higher in the inshore than the offshore area,

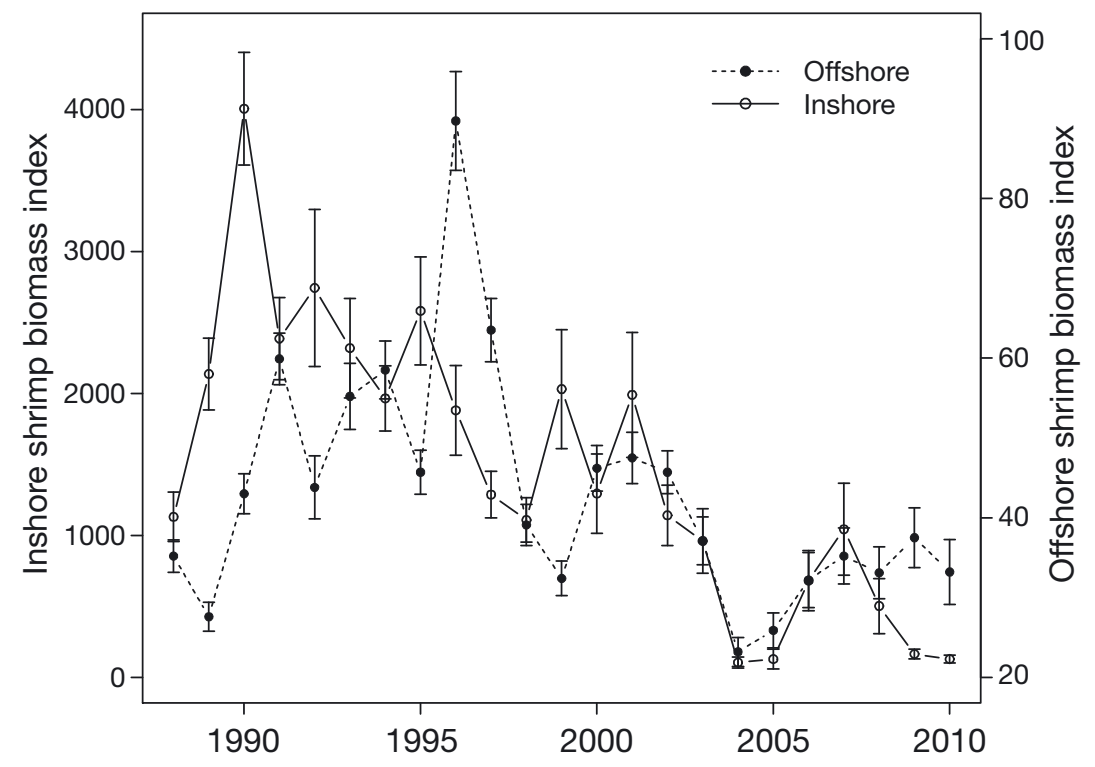

Fig. 2. Pandalus borealis. Northern shrimp biomass indices $( \pm \mathrm{CV}$, the coefficient of variation of the stock size estimate) for inshore and offshore areas 
where they were almost absent (Fig. 3A). The density of small cod in the inshore area varied without trend from 1988 to 2000, but it has been very low since 2001 (Fig. 3A).

The density of large cod was very low in the offshore area from 1988 to 1995, but was generally higher from 1996 to 1998 in both areas (Fig. 3B). This was followed by 2 yr of low catch rates before large cod density again increased; since 2003 it has remained much higher than between 1988 and 1995 (Fig. 3B).

\section{Diet composition}

Cod in the inshore area was on average smaller (mean length: $23.5 \mathrm{~cm}$ ) than in the offshore area (mean length: $56.6 \mathrm{~cm}$ ). Stomach content was not analysed in small cod, and the mean length of cod used for stom-

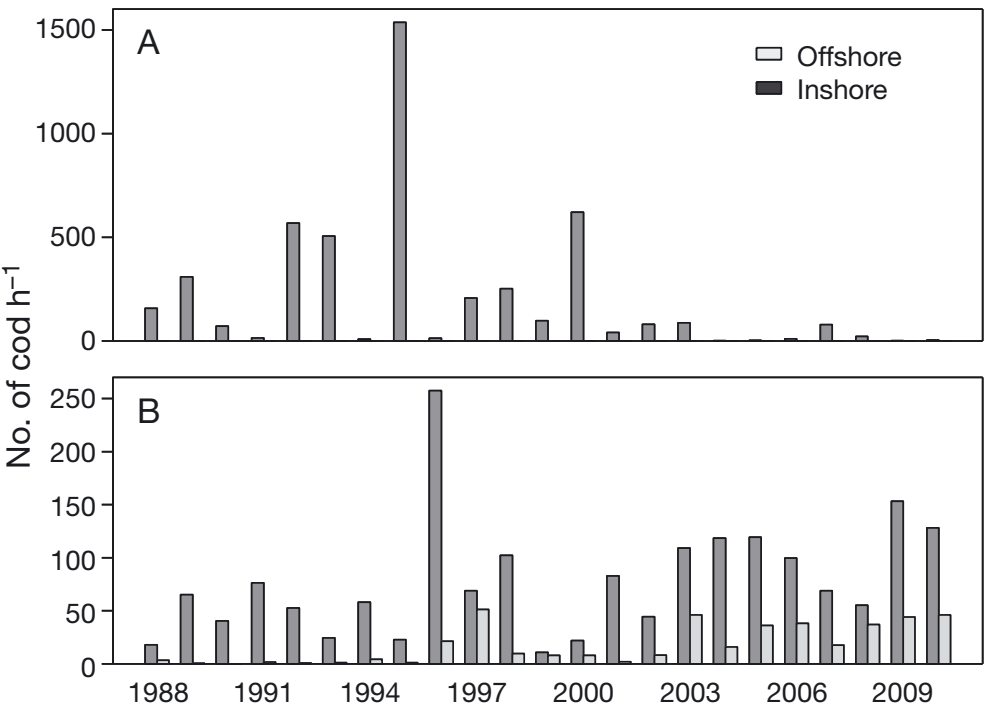

Fig. 3. Gadus morhua. Number of (A) small $(\leq 15 \mathrm{~cm})$ and (B) large $(>15 \mathrm{~cm})$ cod caught per hour in inshore and offshore northern shrimp surveys from 1988 to 2010 ach analysis was 44.1 and $62.6 \mathrm{~cm}$ in the inshore and offshore areas, respectively.

From 1999 to 2010, a total of 2062 and $4859 \mathrm{cod}$ stomachs were examined in the inshore and offshore areas, respectively. The percentage of cod with empty stomachs (Table 1) was higher in the inshore area (15 to $34 \%$ ) than in the offshore area (6 to $17 \%$ ).

The stomach contents were quite variable, with 65 and 105 prey items identified in the inshore and offshore areas, respectively. There were 3 main prey groups for inshore cod and 4 main groups for offshore cod (Fig. 4). For inshore cod, the main prey group was fish, including cod, haddock Melanogrammus aeglefinus, snake blenny Lumpenus lampretaeformis, spotted snake blenny Leptoclinus maculates and herring Clupea harengus. The second main prey group was northern shrimp, and the third main prey group was euphausiids. An obvious shift in prey preference of inshore cod was observed in 2006, when the main prey group became northern shrimp and at the same time the proportion of various fishes decreased (Fig. 4). The main prey group for offshore cod (as for inshore cod) was fish, including Lumpenus spp., Lycodes spp. and long rough dab Hippoglossoides platessoides. The second main prey group was capelin, and the last 2 main prey groups were the 2 shrimp species, northern ambereye and northern shrimp.

The TF values for both inshore and offshore cod differed significantly among years (Kruskal-Wallis test; $p<0.001$ ) and were generally inversely related (Fig. 5A). The TF for inshore cod declined from 1999 to 2003 and has since been highly variable. The TF

Table 1. Gadus morhua and Pandalus borealis. Number of cod sampled in the inshore and offshore northern shrimp areas each year. Percentage of cod observed with empty stomachs, and percentage of cod observed with northern shrimp in the stomach

\begin{tabular}{|lccc|}
\hline & $\mathrm{n}$ & $\begin{array}{c}\text { Empty cod } \\
\text { stomachs }(\%)\end{array}$ & $\begin{array}{c}\text { Northern shrimp in } \\
\text { cod stomachs }(\%)\end{array}$ \\
\hline Inshore & & & \\
1999 & 78 & 30.8 & 48.7 \\
2000 & 164 & 34.1 & 22.0 \\
2001 & 178 & 20.2 & 37.6 \\
2002 & 151 & 19.2 & 28.5 \\
2003 & 165 & 33.3 & 29.7 \\
2004 & 253 & 28.5 & 29.6 \\
2005 & 248 & 31.0 & 20.6 \\
2006 & 115 & 23.5 & 33.9 \\
2007 & 208 & 15.9 & 48.6 \\
2008 & 234 & 15.4 & 52.6 \\
2009 & 133 & 24.8 & 35.3 \\
2010 & 135 & 22.2 & 49.6 \\
Offshore & & & \\
1999 & 422 & 5.7 & 61.8 \\
2000 & 338 & 12.7 & 53.8 \\
2001 & 253 & 8.3 & 57.3 \\
2002 & 351 & 7.4 & 63.2 \\
2003 & 724 & 11.5 & 56.8 \\
2004 & 552 & 12.5 & 53.4 \\
2005 & 514 & 15.4 & 38.9 \\
2006 & 367 & 7.6 & 45.5 \\
2007 & 305 & 15.1 & 47.2 \\
2008 & 350 & 15.7 & 41.7 \\
2009 & 340 & 17.1 & 41.6 \\
2010 & 343 & 14.6 & \\
& & & \\
\hline
\end{tabular}




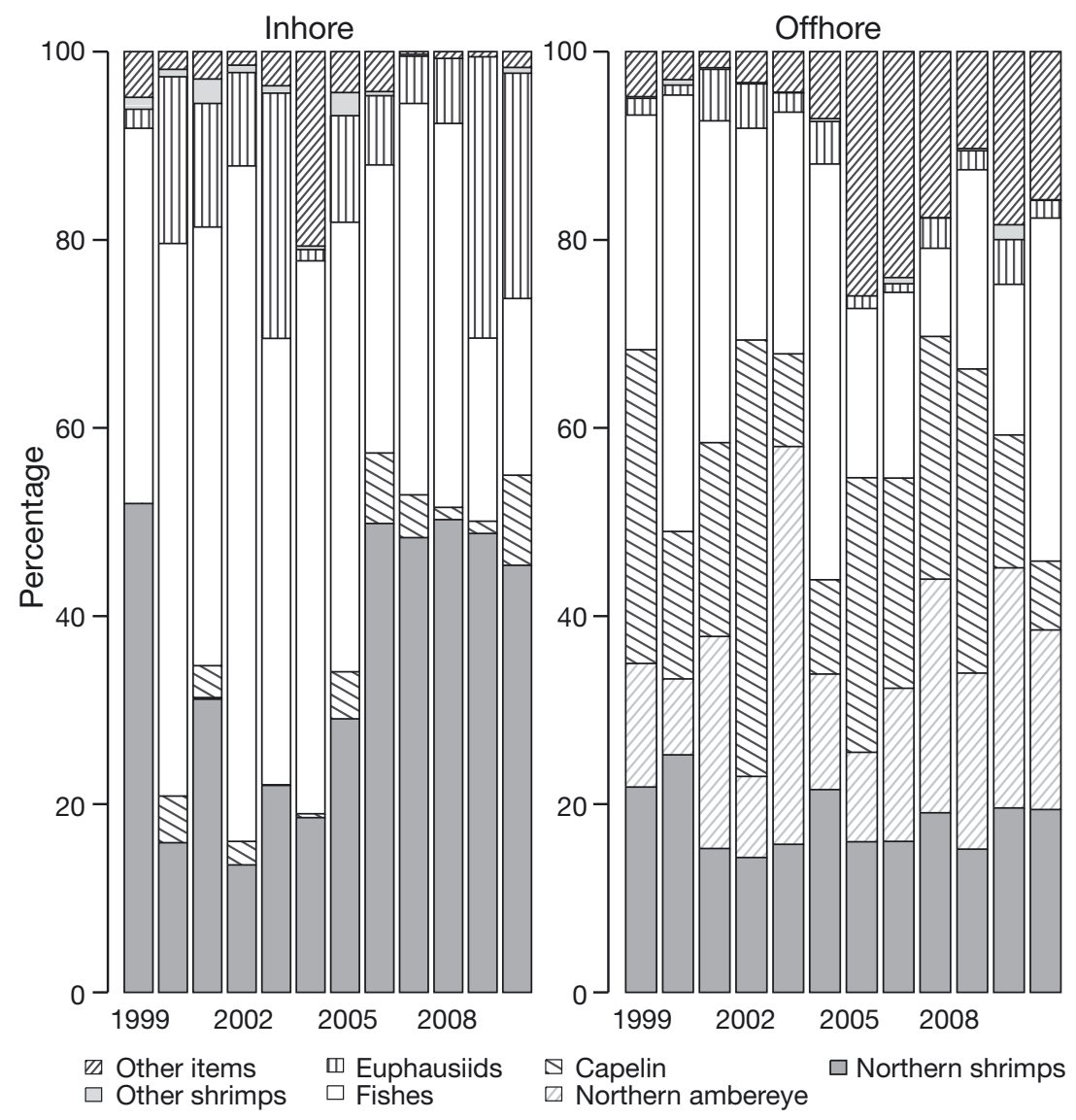

Fig. 4. Gadus morhua. Proportion (\% of total stomach content by mass) of the 7 main prey groups of cod in inshore and off-shore areas from 1999 to 2010

for offshore cod showed clear differences between 2 periods (Fig. 5A). It was much higher than for inshore cod from 1999 to 2003. However, it decreased sharply in 2004 (when the TF for inshore cod increased sharply) and has remained at its lowest level since 2006 (Fig. 5A).

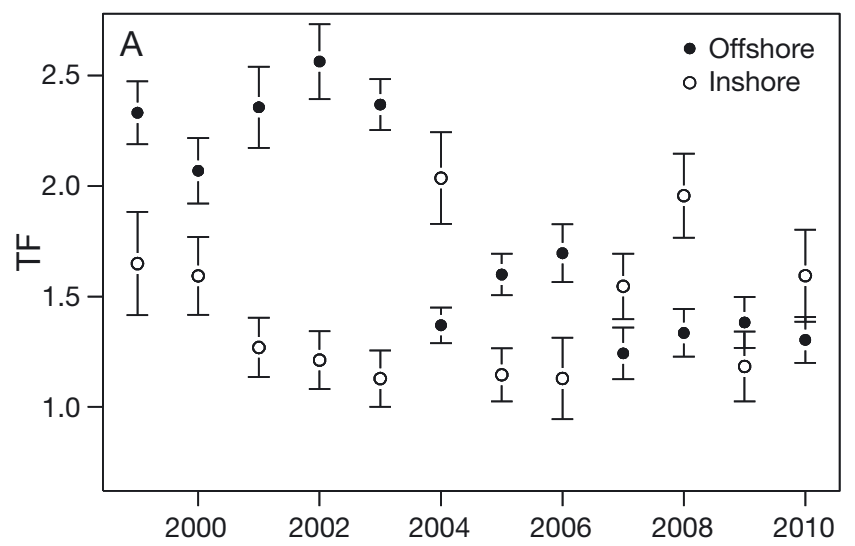

An inverse relationship in SF was also observed between inshore and offshore cod (Fig. 5B). SF increased in the inshore, but decreased in offshore cod (Fig. 5B). Hence, from 2000 to 2003, the SF was higher in offshore cod, but, since 2004, it has been consistently much higher (and more highly variable) in inshore cod.

Higher percentages of cod included northern shrimp in their diet in the offshore area (39 to $63 \%$ ) than in the inshore area (21 to $53 \%$ ) (Table 1). The percentage of cod stomachs containing northern shrimp did not change significantly with increasing cod length in the inshore area $\left(\mathrm{r}^{2}=0.0089, \mathrm{p}=0.405\right.$; Fig. 6A). It did, however, increase significantly with increasing cod length in the offshore area $\left(\mathrm{r}^{2}=0.302, \mathrm{p}<0.001\right.$; Fig. 6A). The percentage by weight of northern shrimp in the cod diet decreased significantly with increasing cod length in both inshore and offshore areas (inshore: $\mathrm{r}^{2}=0.501$; offshore: $\mathrm{r}^{2}=$ 0.766; $\mathrm{p}<0.001$; Fig. 6B).

The relationship between the number of cod caught per hour and the shrimp biomass index was not clear in either the inshore or offshore area (Fig. 7). High cod density did, however, appear to be related to shrimp biomass in both areas. Above average cod catch rates tended to be associated with below average shrimp biomass levels (Fig. 7). In contrast, when cod catch rates were below average, it was equally likely that the shrimp biomass would be below or above average (Fig. 7). Negative effects of

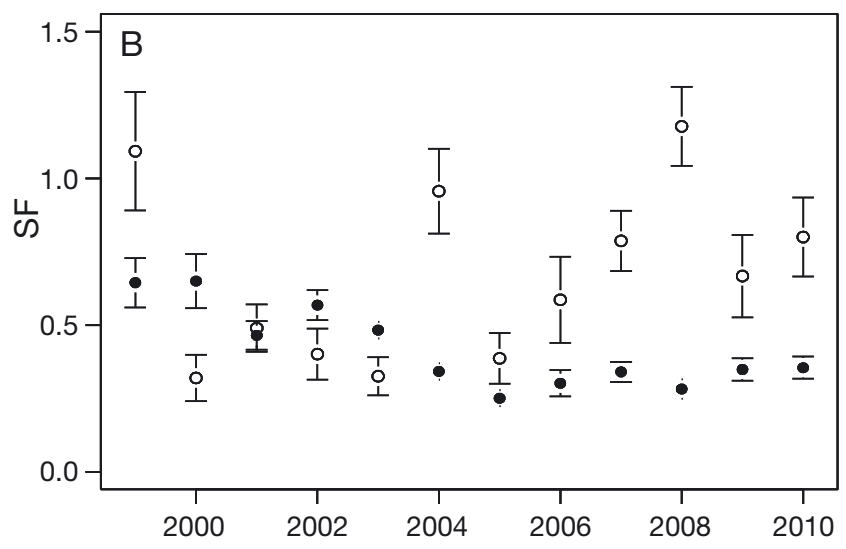

Fig. 5. Gadus morhua and Pandalus borealis. (A) Mean total stomach fullness (TF) and (B) mean shrimp stomach fullness (SF) for cod in inshore $(\mathrm{O})$ and offshore $(\bullet)$ northern shrimp areas off Iceland 

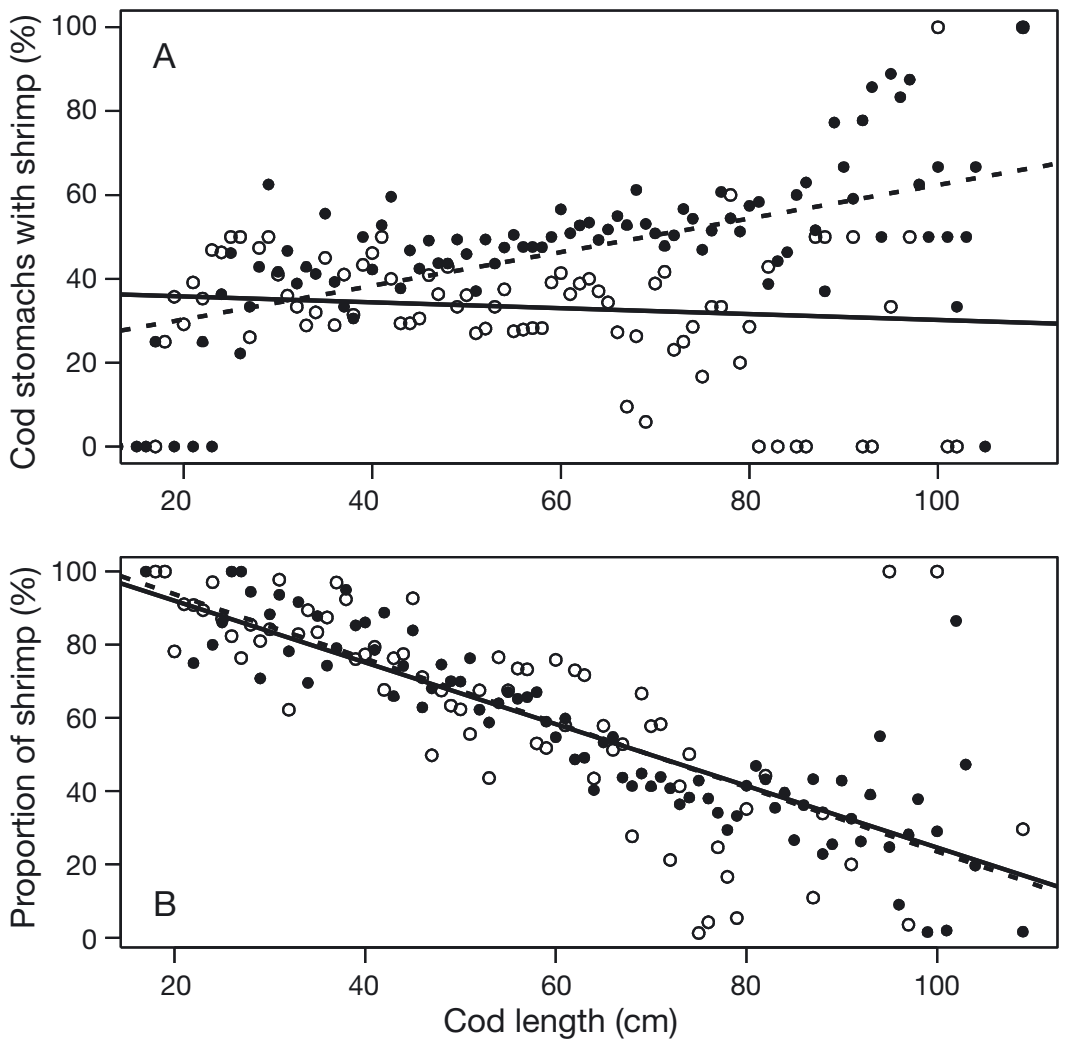

Fig. 6. Gadus morhua and Pandalus borealis. (A) Proportion of cod that had consumed northern shrimp in inshore $(\mathrm{O},-)$ and offshore $(\bullet,--)$ northern shrimp areas. (B) Proportion by weight of northern shrimp in the stomach of cod (cod with no shrimp in the stomach were excluded)

predation on prey biomass are often observed with a lag of $1 \mathrm{yr}$, but the relationships described here did not become clearer when the shrimp biomass index was compared with the cod catch rate in the previous year.

\section{DISCUSSION}

\section{Prey composition}

The main prey types of cod Gadus morhua differed between the 2 areas, but it is common to see diet differences between areas (Lee \& Khan 2000, Rose \& O'Driscoll 2002). Fish size is the most likely candidate factor for explaining the variation in the diet of Icelandic cod (Jaworski \& Ragnarsson 2006). The most important prey types included northern shrimp Pandalus borealis, fish and euphausiids in the inshore area, as opposed to capelin Mallotus villosus, other fish species, northern ambereye Hymenodora glacialis and northern shrimp in the offshore area. Differences between areas in relative importance of the principal prey types was likely due to differences in cod size, with small cod in the inshore area feeding on smaller prey, such as euphausiids, while larger cod in the offshore area prey more heavily on large prey types such as capelin. Euphausiids are known to be of greater importance to small than to large cod (Dalpadado \& Bogstad 2004, Pálsson \& Björnsson 2011). In the inshore area, euphausiids were found in dense groups, a pattern also observed in a nearby fjord, where euphausiids were an important food source for cod (Björnsson et al. 2011).

Prey types are of variable quality, and food of low quality may negatively influence growth, condition and reproductive potential of the fish (Rose \& O'Driscoll 2002). Although cod may be considered opportunistic feeders, they do exhibit distinct prey preferences, and the results of this present study showed indications of selective feeding. From 2006 to 2010, a relatively high biomass of large cod was observed in the inshore area. At the same time, a low percentage of fish (other than capelin) was found in cod stomachs, and high SF was observed despite low shrimp biomass. This could indicate that cod selectively preyed upon northern shrimp when cod density was relatively high and the preferred fish prey was unavailable. In the offshore area, cod seemed to select for capelin and northern ambereye. Capelin is one of the most important prey for cod, and cod liver condition is related to capelin availability (Rose \& O'Driscoll 2002). Northern ambereye is a deepwater, lipid-rich shrimp, with total lipids representing about $44 \%$ of the dry mass, which they accumulate to survive periods of low food supply (Kreibich et al. 2010). Hence, northern ambereye is an energyrich food item. For comparison, total lipids of northern ambereye are twice as high as in northern krill Meganyctiphanes norvegica (Kreibich et al. 2010). Northern ambereye is not very abundant in the offshore survey. However, cod are observed with full stomachs of northern ambereye, indicating selective feeding by cod. As northern ambereye is not found in high abundance in the offshore survey, cod feed on them either in the water column or at greater depths than those sampled in the survey. The reason for the 

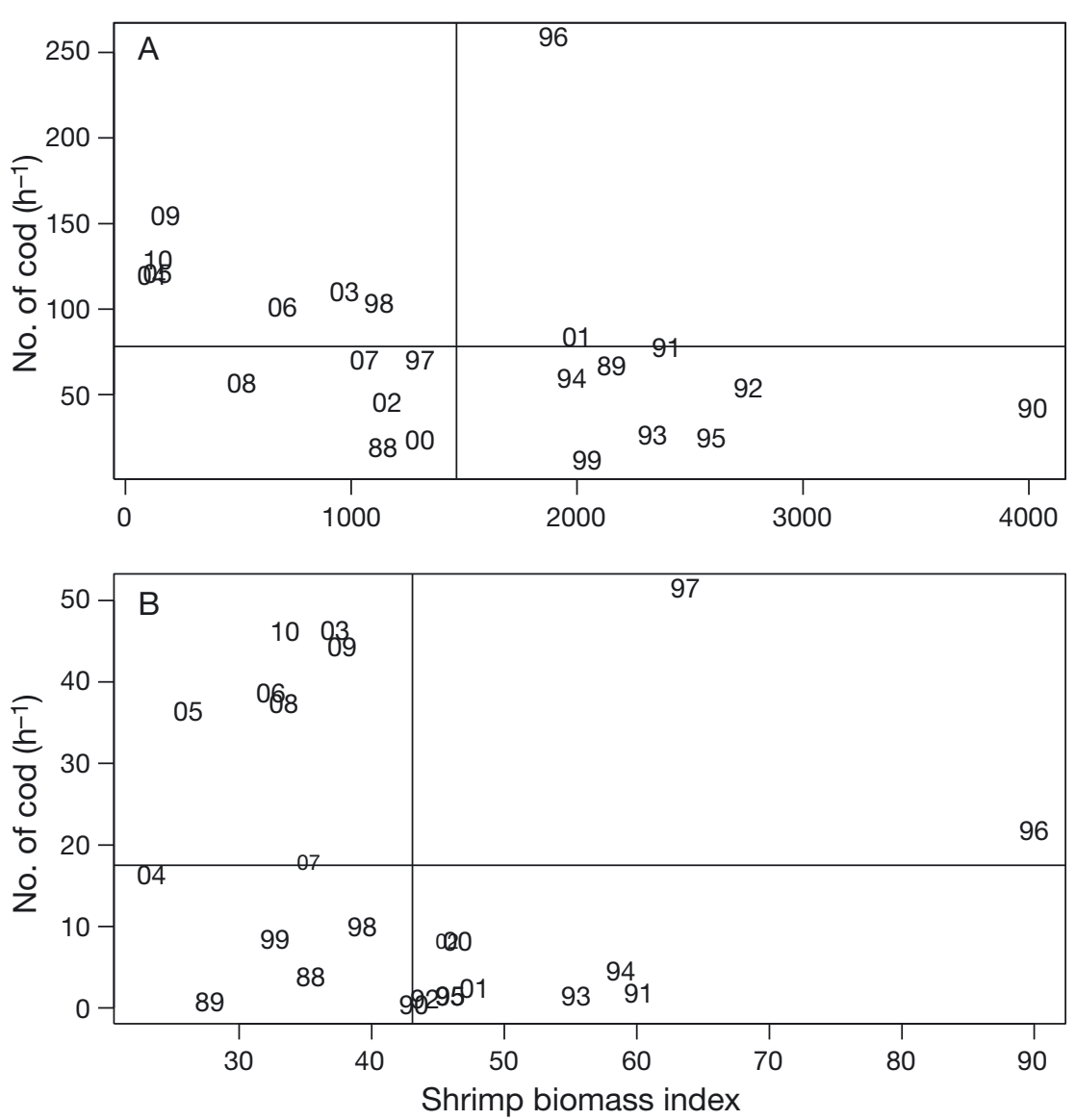

Fig. 7. Gadus morhua and Pandalus borealis. Relationship between shrimp biomass index and number of cod caught per hour in (A) inshore and (B) offshore northern shrimp areas. Lines represent mean shrimp biomass index and mean number of cod caught per hour in each area. Numbers represent sampling years

high frequency of occurrence of euphausiids in cod stomachs, despite their relatively low lipid content, could be that euphausiids are found in dense patches and little foraging time and energy is used for hunting.

The cod diet generally reflects prey availability, and the overlap between cod and its prey is reflected in the diet. Therefore, cod may be categorized as opportunistic feeders. In 2004, there were some changes in the offshore area; a high proportion of cod had empty stomachs, and the TF decreased sharply. At the same time, the proportion of fish (except capelin) decreased in cod stomachs and the proportion of other prey types increased. Comparison of the diet of northwest Atlantic cod with prey distribution has shown that most major prey species were consumed when they were abundant and their distribution overlapped with that of cod (Link \& Garrison 2002). As the diet of predatory fishes partly reflects the prey availability in the area (Fahrig et al. 1993), changes in diet composition may indicate shifts in distribution and/or abundance of prey species. The observed changes in the present study, along with the fact that northern shrimp biomass was at historically low levels in 2004, may indicate some changes in the ecosystem north of Iceland during this time.

\section{Prey consumption}

Two factors, cod size and sea temperature, are most important when comparing prey consumption between the 2 study areas. Cod inhabiting the 2 areas were of different size classes. Small cod were most common in the inshore area, while cod were larger in the offshore area. The inshore area is a known nursery area, while various offshore and inshore areas are feeding areas. The 2 areas, therefore, play different roles in the life history of the cod. Even though the proportion of cod consuming northern shrimp increased with increasing fish length (in the offshore area), the importance of northern shrimp in the diet of cod decreased with length in both areas. These results are in accordance with earlier studies in Icelandic waters (Pálsson \& Björnsson 2011), the Barents Sea (Berenboim et al. 2000) and Pavlof Bay, Alaska (Albers \& Anderson 1985). That does, however, not necessarily mean lower consumption of northern shrimp by large than by small cod, as large cod have a greater total consumption than small cod and may therefore consume more shrimp. Further, large cod (>35 cm TL) is the main predator on northern shrimp in Icelandic waters (Jaworski \& Ragnarsson 2006), and, before the collapse of the northern Gulf of St. Lawrence cod stock, large cod was also the main predator in that area (Savenkoff et al. 2007). Stomach examination was not conducted for small ( $<15 \mathrm{~cm}$ TL) cod in this study, but other studies have shown that northern shrimp is not an important prey type for such small cod in other areas (Lilly et al. 2000, Dalpadado \& Bogstad 2004).

There are substantial differences in bottom temperature between the 2 areas, with annual nearbottom temperatures ranging from 0.4 to $1.8^{\circ} \mathrm{C}$ in the offshore area and 6.8 to $9.1^{\circ} \mathrm{C}$ in the inshore area. 
Due to the inflow of the cold water masses of the East Greenland Current, the area north and northeast of Iceland is the coldest around the country (Stefánsson 1962, Malmberg \& Valdimarsson 2003). Consumption may be significantly different between areas due to the different temperature regimes. The rate of handling, eating and digesting a meal increases with temperature (Wootton 1998, Grigoriou \& Richardson 2008), escalating the energy demand in areas with high temperature. Furthermore, experimental studies have shown that the stomach evacuation rate and, hence, consumption, increases with temperature (dos Santos \& Jobling 1991). Consumption is therefore expected to be lower in the offshore area than in the inshore area. Little change in bottom temperature has been observed in the offshore area, but it did increase in the inshore area during the study period, leading to increased food requirements in recent years. Furthermore, laboratory experiments have demonstrated that gastric evacuation of small cod is faster than that of large cod when fed similar-sized meals relative to their body weight (dos Santos \& Jobling 1995). This would suggest a greater food requirement and greater consumption per body weight for inshore than for offshore cod.

\section{Effects of predation by cod on northern shrimp}

In this study the predation by cod on northern shrimp was studied in 2 different areas off Iceland. Even though some of the main prey groups differed between the 2 areas, northern shrimp was one of the major prey types of cod in both the inshore and offshore areas. Low northern shrimp biomass has been evident in both areas in recent years, while cod density has remained high, implying that predation by cod had a negative effect on northern shrimp biomass.

Given the importance of northern shrimp as prey for cod, top-down control might be expected. The results of the present study suggest that cod had an adverse effect on northern shrimp abundance in both areas, as northern shrimp biomass was more likely to be below average in years when cod abundance was above average. The impact of cod predation on northern shrimp populations has been ambiguous. Several studies have suggested that cod control shrimp populations (Berenboim et al. 2000, Worm \& Myers 2003), and the abundance of northern shrimp has been noted to increase markedly following the collapse of demersal fish populations, such as on the northeast Newfoundland shelf (Lilly et al. 2000) and in Greenland (Hamilton et al. 2003). In the Gulf of Alaska, cod predation has played a role in keeping the reduced shrimp stocks from rebuilding (Albers \& Anderson 1985). Consumption by cod has also been noted as the main cause of shrimp mortality in the Gulf of St. Lawrence (Savenkoff et al. 2007), and a positive relationship was found between northern shrimp consumption by cod and shrimp biomass in Icelandic waters (Pálsson \& Björnsson 2011). However, other studies have demonstrated that shrimp populations are not regulated entirely by cod predation (Lilly et al. 2000, Mueter \& Norcross 2000).

\section{Predation by other species}

Northern shrimp is an important prey for other fish species (Pálsson 1983, Parsons 2005), and the consumption by cod is only a part of the total removals by all predators. Greenland halibut Reinhardtius hippoglossoides is the most important bycatch in the offshore northern shrimp fishery in Icelandic waters and is an important predator on shrimp (Haug \& Gulliksen 1982, Solmundsson 2007). In the period from 1987 to 1989, a feeding study of Greenland halibut on the offshore northern shrimp grounds revealed that northern shrimp contributed $6 \%$ by weight to the total diet (Solmundsson 2007). Another possibly important predator that is common in the offshore survey is eelpout Lycodes spp. In a study in West Greenland waters, northern shrimp contributed $81.5 \%$ by weight to the total diet of eelpouts (Pedersen \& Riget 1991). Furthermore, in a study from 1993 in the offshore area, $>70 \%$ of the diet of the largest eelpouts (L. eudipleurostictus and L. vahlii) were shrimps, euphausiids and mysids (Valtýsson 1997). In the inshore area, haddock Melanogrammus aeglefinus abundance increased after 1997 (Skúladóttir et al. 2001) and whiting Merlangius merlangus after 2001 (Anonymous 2010). Northern shrimp is not a major prey type of haddock (Björnsson et al. 2011, Pálsson \& Björnsson 2011), but has been noted in the stomach of both haddock and whiting.

\section{Conclusions}

The results of the present study suggest that cod had an adverse effect on northern shrimp abundance in both areas, as northern shrimp biomass was more likely to be below average in years when cod abundance was above average. Northern shrimp was a more important prey type of cod in the inshore than 
in the offshore area, and in some years it represented about $50 \%$ of the diet. Other important prey types, such as capelin and northern ambereye, which cod selectively feed on in the offshore area, were rare in the inshore area. Higher temperature in the inshore than offshore area implies a greater food requirement and higher consumption. Accordingly, cod is likely to have a greater impact on northern shrimp in the inshore than in the offshore area.

Although cod predation has an impact on northern shrimp biomass, other factors, such as fishing (Savenkoff et al. 2007), ocean climate variability (Wieland 2005, Ouellet et al. 2011), size of areas of suitable habitat and larval transport (Koeller 2000) may also be important factors in regulating shrimp abundance. Further work is needed to evaluate how northern shrimp may respond to changes in predator abundances in relation to other factors, such as temperature, other ocean climate variables, abundance of other prey, and the distribution of predators and prey.

Acknowledgements. We thank the captains and crews of RS 'Bjarni Sæmundsson' and 'Dröfn' which were used for sampling. Thanks to Guðmundur Skúli Bragason, Stefán H. Brynjólfsson and all the researchers working aboard for sampling and analyses of the stomach content. We thank Björn Björnsson, Jón Sólmundsson, Heather Philp, Hrafnkell Eiríksson, the guest editor and 4 anonymous reviewers for valuable comments on an earlier version of the manuscript.

\section{LITERATURE CITED}

Albers WD, Anderson PJ (1985) Diet of Pacific cod, Gadus macrocephalus, and predation on the northern pink shrimp, Pandalus borealis, in Pavlof Bay, Alaska. Fish Bull 83:601-610

Anonymous (2010) State of marine stocks in Icelandic waters 2009/2010. In: Prospects for the quota year 2010/2011. Marine Research, Fjölrit

Berenboim BI, Dolgov AV, Korzhev VA, Yaragina NA (2000) The impact of cod on the dynamics of Barents Sea shrimp (Pandalus borealis) as determined by multispecies models. J Northwest Atl Fish Sci 27:69-75

Björnsson B, Reynisson P, Solmundsson J, Valdimarsson H (2011) Seasonal changes in migratory and predatory activity of two species of gadoid preying on inshore northern shrimp Pandalus borealis. J Fish Biol 78 : 1110-1131

> Campbell N, Neat F, Burns F, Kunzlik P (2011) Species richness, taxonomic diversity, and taxonomic distinctness of the deep-water demersal fish community on the Northeast Atlantic continental slope (ICES Subdivision VIa). ICES J Mar Sci 68:365-376

> Dalpadado P, Bogstad B (2004) Diet of juvenile cod (age 0-2) in the Barents Sea in relation to food availability and cod growth. Polar Biol 27:140-154

dos Santos J, Jobling M (1991) Factors affecting gastric evacuation in cod, Gadus morhua L., fed single-meals of natural prey. J Fish Biol 38:697-713

dos Santos J, Jobling M (1995) Test of a food consumption model for the Atlantic cod. ICES J Mar Sci 52:209-219

Fahrig L, Lilly G, Miller DS (1993) Predator stomachs as sampling tools for prey distribution: Atlantic cod (Gadus morhua) and capelin (Mallotus villosus). Can J Fish Aquat Sci 50:1541-1547

> Fraser HM, Greenstreet SPR, Fryer RJ, Piet GJ (2008) Mapping spatial variation in demersal fish species diversity and composition in the North Sea: accounting for species and size-related catchability in survey trawls. ICES J Mar Sci 65:531-538

Grigoriou P, Richardson CA (2008) The effect of ration size, temperature and body weight on specific dynamic action of the common cuttlefish Sepia officinalis. Mar Biol 154: 1085-1095

Hamilton LC, Brown BC, Rasmussen ROLE (2003) West Greenland's cod-to-shrimp transition: local dimensions of climatic change Disko. Arctic 56:271-282

Haug T, Gulliksen B (1982) Size, age, occurrence, growth, and food of Greenland halibut, Reinhardtius hippoglossoides (Walbaum) in coastal waters of western Spitzbergen. Sarsia 67:293-297

Jaworski A, Ragnarsson SA (2006) Feeding habits of demersal fish in Icelandic waters: a multivariate approach. ICES J Mar Sci 63:1682-1694

> Jónsdóttir ÓDB, Imsland AK, Nævdal G (1998) Population genetic studies of northern shrimp, Pandalus borealis, in Icelandic waters and the Denmark Strait. Can J Fish Aquat Sci 55:770-780

Koeller PA (2000) Relative importance of abiotic and biotic factors to the management of the northern shrimp (Pandalus borealis) fishery on the Scotian shelf. J Northwest Atl Fish Sci 27:21-33

Kreibich T, Hagen W, Saborowski R (2010) Food utilization of two pelagic crustaceans in the Greenland Sea: Meganyctiphanes norvegica (Euphausiacea) and Hymenodora glacialis (Decapoda, Caridea). Mar Ecol Prog Ser 413: 105-115

> Lee EM, Khan RA (2000) Length-weight-age relationships, food, and parasites of Atlantic cod (Gadus morhua) off coastal Labrador within NAFO Divisions $2 \mathrm{H}$ and $2 \mathrm{~J}-3 \mathrm{~K}$. Fish Res 45:65-72

Lilly GR, Parsons DG, Kulka DW (2000) Was the increase in shrimp biomass on the northeast Newfoundland Shelf a consequence of a release in predation pressure from cod? J Northwest Atl Fish Sci 27:45-61

Link J, Garrison L (2002) Trophic ecology of Atlantic cod Gadus morhua on the northeast US continental shelf. Mar Ecol Prog Ser 227:109-123

Magnússon KG, Pálsson ÓK (1989) Trophic ecological relationships of Icelandic cod. Rapp Proces 188:206-224

Malmberg SA, Valdimarsson H (2003) Hydrographic conditions in Icelandic waters, 1990-1999. ICES Mar Sci Symp 219:50-60

Mehl S (1989) The northeast Arctic cod stock's consumption of commercially exploited prey species in 1984-1986. Rapp Proces 188:185-205

Mueter FJ, Norcross BL (2000) Changes in species composition of the demersal fish community in nearshore waters of Kodiak Island, Alaska. Can J Fish Aquat Sci 57: 1169-1180

Nielsen JR, Andersen M (2001) Feeding habits and density patterns of Greenland cod, Gadus ogac (Richardson, 1836), at West Greenland compared to those of the co- 
existing cod, Gadus morhua L. J Northw Atl Fish Sci 29:1-22

Ouellet P, Fuentes-Yaco C, Savard L, Platt T and others (2011) Ocean surface characteristics influence recruitment variability of populations of northern shrimp (Pandalus borealis) in the Northwest Atlantic. ICES J Mar Sci 68:737-744

Pálsson ÓK (1983) The feeding habits of demersal fish species in Icelandic waters. J Mar Res Ins 7:1-60

Pálsson ÓK, Björnsson H (2011) Long-term changes in trophic patterns of Iceland cod and linkages to main prey stock sizes. ICES J Mar Sci 68:1488-1499

Parsons DG (2005) Predators of northern shrimp, Pandalus borealis (Pandalidae), throughout the North Atlantic. Mar Biol Res 1:48-58

Pedersen SA, Riget F (1991) Preliminary studies on feeding habits of demersal fish species in West Greenland waters with special emphasis on predation on shrimp. NAFO SCR Doc 91:1-13

Rose GA, O'Driscoll RL (2002) Capelin are good for cod: Can the northern stock rebuild without them? ICES J Mar Sci 59:1018-1026

Savenkoff C, Swain DP, Hanson JM, Castonguay M and others (2007) Effects of fishing and predation in a heavily exploited ecosystem: comparing periods before and after the collapse of groundfish in the southern Gulf of St. Lawrence (Canada). Ecol Model 204:115-128

Skúladóttir U, Bragason GS, Brynjólfsson S, Valtýsson HP (2001) Hrun rækjustofna á grunnslód (Collapse of the

Submitted: November 4, 2011; Accepted: August 1, 2012 shrimp population in inshore areas). Ægir 94:34-39 (in Icelandic)

Solmundsson J (2007) Trophic ecology of Greenland halibut (Reinhardtius hippoglossoides) on the Icelandic continental shelf and slope. Mar Biol Res 3:231-242

Sousa P, Azevedo M, Gomes MC (2006) Species-richness patterns in space, depth, and time (1989-1999) of the Portuguese fauna sampled by bottom trawl. Aquat Living Resour 19:93-103

Sparre P, Venema SC (1989) Introduction to tropical fish stock assessment. Part 1-Manual. Fisheries Technical Paper 306/1, Rev. 2. FAO, Rome

Stefánsson U (1962) North Icelandic waters. J Mar Res Ins 3: $1-269$

Stefánsson G, Skuladottir U, Steinarsson BAE (1998) Aspects of the ecology of a boreal system. ICES J Mar Sci 55: 859-862

Valtýsson HP (1997) Feeding habits and distribution of eelpouts in Icelandic waters. Mar Res Fjölrit 57:89-99 (in Icelandic)

Wieland K (2005) Changes in recruitment, growth, and stock size of northern shrimp (Pandalus borealis) at West Greenland: temperature and density-dependent effects at released predation pressure. ICES J Mar Sci 62:1454-1462

Wootton RJ (1998) Ecology of teleost fishes. Kluwer Academic Publishers, Dordrecht

> Worm B, Myers RA (2003) Meta-analysis of cod-shrimp interactions reveals top-down control in oceanic food webs. Ecology 84:162-173

Proofs received from author(s): October 12, 2012 